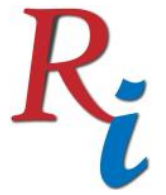

Asia Proceedings of Social Sciences

(APSS)

www.readersinsight.net/APSS

\title{
AfFordable Housing Provision using Public PRIVATE PARTNERSHIP IN ABUJA NIGERIA: A REVIEW
}

\section{Yahaya Ahmed*}

Faculty of Built Environment and surveying Universiti Teknologi Malaysia, 81310 Skudai Johor, Malaysia

\section{Atan Bin Sipan}

Faculty of Built Environment and surveying

Universiti Teknologi Malaysia, 81310 Skudai, Johor

Malaysia

*Corrosponding author's Email: yahmednas1@gmail.com

Peer-review under responsibility of $3^{\text {rd }}$ Asia International Multidisciplanry Conference 2019 editorial board (http://www.utm.my/asia/our-team/) (C) 2019 Published by Readers Insight Publisher, lat 306 Savoy Residencia, Block 3 F11/1,44000 Islamabad. Pakistan, info@ readersinsight.net This is an open access article under the CC BY-NC-ND license (http://creativecommons.org/licenses/by-nc-nd/4.0/). 


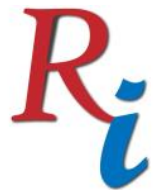

Asia Proceedings of Social Sciences

(APSS)

www.readersinsight.net/APSS

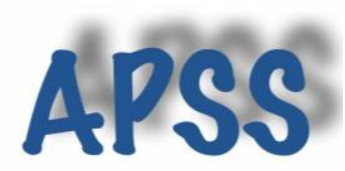

Rese a r ch H i g h I ight s

Provision of housing has become a global issue. According to the United Nations, housing is lacking in almost all societies among developing countries due to population growth and urbanization (UN-Habitat, 2006). Thus, private Partnership has recently been recognized as an option to end the crisis during the shortage of affordable housing and housing in the country by the Nigerian government in line with the UN's recommendations (Ibem and Aduwo, 2012). This study relies on the findings of the preview study to identify PPP challenges for affordable housing provision in Abuja. The findings identify the challenges of PPP for affordable in Nigeria. However, this study proposes a way to improve the delivery system and ensure better results.

\section{Research Objectives}

The study has review the challenges of PPP for provision of affordable housing in Abuja. The review of the study indicate that PPP has not made any significant contribution in providing affordable housing; rather it is suddenly change towards providing housing for high- and middle-income earners. However, the studies (Roberts, 2013 ;. Ibem \& Aduwo2012; Mabogunje, 2011; THISDAY, 2009; Abosede, 2006; Akeju, 2007; Agbola, 2005; Adediji, 2006; Kuye, 2006; Akeju, 2007; Tabiti \& Tiamiyu, 2002; Ogbuozobe \& Ogu, 2001; Mabogunje, 2001; Olatubara \& Agbola, 1993) identify a number of constraints to the implementation of the PPP for affordable housing any provision such as: acquisition and access to land, access to adequate housing finance, high interest rates, difficulties access to mortgage facilities and land titles, ownership and land management, poor infrastructure facilities, depending on the foreign construction materials, migration of large rural towns, poor implementation of the housing policy, cost recovery problem, economic problems, high building standards in the PPP scheme among others.

\section{Methodology}

The use of Textbooks, journal articles, reports, papers, but a small number is used by this research work to complete research in the existing field of knowledge and current PPP research agenda, in contrast, PPP policy documents, gazette guidelines, and PPP housing allocation reports in Abuja. This is also include newspaper articles to understand the planned PPP housing projects in Nigeria.

\section{Results}

The result from the literature found that acquisition and access to land, access to adequate housing finance, high interest rates, difficulties access to mortgage facilities and land titles, ownership and land management, poor infrastructure facilities, depending on the foreign construction materials, migration of large rural towns, poor implementation of the housing policy, cost recovery problem, economic problems, high building standards in the PPP scheme among others (Roberts, 2013 ;. Ibem \& Aduwo2012; Mabogunje, 2011; THISDAY, 2009; Abosede, 2006; Akeju, 2007; Agbola, 2005; Adediji, 2006; Kuye, 2006; Akeju, 2007; Tabiti \& Tiamiyu, 2002; Ogbuozobe \& Ogu, 2001; Mabogunje, 2001; Olatubara \& Agbola, 1993), as the mojor challenges of PPP for housing provosion in Nigeria. 


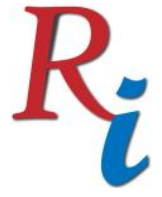

\section{Asia Proceedings of Social Sciences \\ (APSS) \\ www.readersinsight.net/APSS}

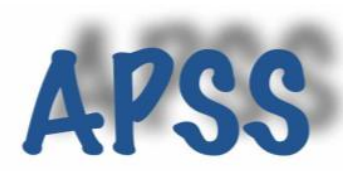

\section{Findings}

Based on a critical review of the PPP challenge for affordable housing in Nigeria, I found that the majority of literary surveys focused on (Acquisition and access to land, access to adequate housing financing, access difficulties to mortgage and land titles, Ownership and management land, weak Infrastructure facilities, Depending on foreign construction materials, Large rural urban migration, Implementation of poor housing policies, Cost recovery problems, Economic problems, high building standards in PPP schemes on housing affordability parameters using PPP This is a fact that the government failed (Makinde 2014.).

\section{Acknowledgement}

The author is grateful to Allah SWT for giving me the ability to write this work. Special honor to my supervisor Ass. Prof Dr Ibrahim Atan Bin Sipan from the Department of Property Management, Faculty of Environment Building and survey, Universiti Teknologi Malaysia, 81310 Skudai, Johor, Malaysia for taking the time to share his knowledge of research with me and giving me full support to carry out my research wishes to say thanks to the organization and TETFund for intervention and support for my research in Malaysia. I would like to thank UTM for giving me an opportunity to become a research student in his field of study, thank UTM.

\section{References}

Abosede F. B. (2006) Housing in Lagos Mega-City - Improving Livability, Inclusion and Governance, being a paper presented at the International Conference on Building Nigeria's Capacity to Implement Economic, Social and Cultural Rights: Lessons Learned, Challenges and the Way Forward, Abuja, Online version available http://www.serac.org/Publications/Hon\%20Abosede\%27s\%20Paper.pdf )

Adediji, Y. M. D. (2006). Affordable and Functional Housing in a Developing Economy: A case study of Nigeria. Journal of Land Use and Development Studies, Vol. 2 (1), 113-120.

Agbola, T. (2005a) The Housing Debacle, Inaugural Lecture Delivered at the University of Ibadan, Ibadan, 4 August.

Akeju, A. A. (2007) Challenges to Providing Affordable Housing in Nigeria. Paper Presented at 2nd Emerging Urban Africa International Conference on Housing Finance in Nigeria. Held at SheuYa-adua Centre, Abuja, Nigeria. October 17th - 19th 2007.

Ibem, E. O. \& Aduwo, E. B. 2012. Public-Private Partnerships (PPPs) in Urban Housing in Nigeria: Evidence from Ogun State. International Journal Of Architecture and Urban Development, 2.

Kuye (2006) Mortgage Financing in Developing Countries, in Agbola, T., Egunjobi, L. \& Olatubara, C. (eds) Housing Development and Management: A Book of Readings, Ibadan, DURP, University of Ibadan. p.627-694

Ogbuozobe, J. E. \& Ogu, V. I. 2001. Housing policy in Nigeria: towards enablement of private housing development. Habitat International, 25, 473-492.

Olusola Oladapo Makinde 2014. Housing delivery system, need and demand Environ Dev Sustain (2014) 16:49_ 69 DOI 10.1007/s10668-013-9474-9

Roberts, R. E. 2013. The Nigerian Middle-Class And Development [Online].

Tabiti S. \& Tiamiyu T. (2002) Housing Policies and Programmes, a seminar paper delivered at a Housing Seminar of the Centre for Urban and Regional Planning.University of Ibadan, Ibadan.

ThisDay (2009) Nigeria: MDGs - Poverty Rate Rises to 76 Percent - UN, ThisDay [Online] Friday 27 February. Availableat:http://allafrica.com/stories/200902270161.html [Accessed 6 July, 2018].

UN-HABITAT (2006). Public-Private Partnerships in enabling shelter strategies. Nairobi: United. 